\title{
ETHNOPEDAGOGY AS A METHOD IN THE CRISIS OF THE NEW CENTURY (TAKING INTO ACCOUNT THE ADYGEYAN EXPERIENCE)
}

\author{
(C) Fatimet N. Khuako
}

\author{
Maykop State Technological University, \\ Maykop, Republic of Adygea, Russian Federation \\ fatimah2@mail.ru
}

The relevance of the presented article is due to the processes of globalization taking place in the world space, including the post-industrial technocracy, which is evident today. The crisis of individual consciousness that arises in these conditions, primarily affecting young people, requires the derivation of new didactic formulas. In this case methods include observation, analytical comparison, synthetic structuring. Folk pedagogy in the North Caucasus (in particular, among the Circassians), presented in the article as a possible methodological solution, is capable of helping in the formation and instilling of the required system of values in a teenager, bypassing the complications existing in the Russian Federation: 1) bilingualism and 2) society. The main goal was to study the theoretical and methodological foundations of national (in particular, Adyghe) ethnopedagogy as a rich didactic resource, the study of which contributes to the achievement of tactical educational tasks. As it was revealed in the course of the study, the inclusion of ethno-pedagogical means in the educational scheme is hampered today due to insufficient applied knowledge. The inculcation of individual dominants at all times is clearly connected by the national beliefs of native speakers, which is directly reproduced in ethnic techniques. Thus, in general: 1) in pedagogical practice, if possible, one should rely on the ethnopedagogical information of previous generations, but 2) at the same time, it is necessary to instill in the student an interest in scientific knowledge and the process.

Key words: global crisis, Adyghe culture, ethnopedagogy, methodological attitudes, ethnoconsciousness, totalitarianism.

\section{[Ф.Н. Хуако Этнопедагогика как метод в кризис нового века (с учетом адыгского опыта)]}

Актуальность представленной статьи обусловлена протекающими на мировом пространстве процессами глобализации, включающими явную сегодня постиндустриальную технократию. Возникающий в этих условиях кризис индивидуального сознания, в первую очередь, отражающийся на молодежи, требует выведения новых дидактических формул. Методы в этом случае включают: наблюдение, аналитическое сопоставление, синтетическое структурирование. Народная педагогика на Северном Кавказе (в частности, у адыгов), представляемая в статье как возможный методологический выход, способна помочь в формировании и в привитии подростку требуемой системы ценностей, минуя имеющуюся в РФ осложненность: 1) двуязычием и 2) социумом. Основной целевой установкой выступило исследование теоретико-методологических основ национальной (в частности, адыгской) этнопедагогики как насыщенного дидактического ресурса, изучение коего содействует достижению тактических образовательных задач. Как было выявлено в ходе исследования, включение этнопедагогических средств в образовательную схему затрудняется сегодня вследствие недостаточной прикладной изученности. Привитие индивидуальных доминант во все времена четко связано общенародными убеждениями носителей языка, что прямым текстом воспроизводится в этнических методиках. Тем самым, в целом: 1) в педагогической практике по возможности следует опираться на этнопедагогические сведения предыдущих поколений, но 2) при этом необходимо привитие учащемуся интереса к научному знанию и процессу.

Ключевые слова: глобальный кризис, адыгская культура, этнопедагогика, методические установки, этносознание, тоталитаризм.

Fatimet N. Khuako - Ph.D. (Advanced Doctorate) in Philology, Professor, Maykop State Technological University, Maykop, Republic of Adygea, Russian Federation.

Хуако Фатимет Нальбиевна - доктор фрилологических наук, профрессор, Майкопский государственный технологический университет, г. Майкоп, Республика Адыгея, Российская Федерация. 
The world civilization enters the technocratic temporary environment, adapting to it by means of the newly emerged value scale. The North Caucasus is one of the most ethnically saturated zones of the Russian Federation. Today's required refreshing of the existing social reality expects not only a multifaceted, detailed examination of the past, but also a thoughtful, both social and personal comprehension of the issues of ethnic restoration. Developed at the end of the last century, domestic socio-political circumstances made it possible to raise the importance of the ethnic factor in the realities of life, allowed an attempt to turn to the line of strengthening national education, as well as restoring the ethnic group in its cultural priority. Several dozen nations are rooted in the North Caucasian geographic field, each of which carries a long-standing (sometimes antique), colourful and original cultural load, a rare pedagogical load collected for centuries (sometimes millennia) in the most difficult life situations. This is, in fact, equipment, which has been constantly improved and progressed through the mutual penetration of neighboring national cultures.

The crisis caused by today's technocracy both in the world and in the region under consideration allows analysts to assert the following: the negative transformations that swept science, jurisdiction, finance and culture, did not spare the educational sphere either. Such negative pressure often results in clear examples of immorality and so-called indifference among teenagers, anger and meaningful trampling of ethnic memory, selfpraise and contempt for others. As American psychologist Bill Ridler describes such a process today, "from your earliest childhood you began to study and evaluate your abilities. You were small and helpless then. <...> At that time, everyone around was bigger, smarter, more capable than you. And it may very well be that, evaluating your strengths from such a disadvantageous position, you decided that your abilities are not enough" [4, p. 10]. In today's high-speed realities, it is sometimes really difficult for a youth to find himself and develop his own life philosophy that can help him continue to exist with dignity. Or, for example, here is how Mensah Farouq Sessah describes the need for reverence and respect for science in developing countries in one of the Western journals of the 1920s describing the economic difficulties existing in the world today: "The solution to the above situations is to develop and implement effective scientific and technical education at all levels of education, especially at the pre-university level. Such training programs should cultivate the spirit of innovation and change that allows people to create new things and find the best" $[1, p$. 1117].

It goes without saying that the unconditional path from the above-described hole cannot be composed without competent positive transformations in all layers of society, which, in turn, are built by an educational system that has developed a national methodology for centuries. Theoretical and applied approaches to the existing difficulties are permissible through multifaceted consideration and thoughtful perception of methodological thoughts and tests in ethnic pedagogy with their subsequent possible application in today's systemic pedagogy (both secondary and higher education). The educational mechanism must and is able to guarantee the chronic inheritance and progressiveness of ethnic culture, instilling a respectful and respectful view of the past and art of a particular nation. It is the class and the teacher who are able to direct the youth in the exact direction, to help him develop aspirations on the basis of the instantly transforming globalization. A multifaceted collection of ethnic qualities and characteristics in the educational complex demanded by the youth environment can be considered the decisive democratic (including regional) moment of the desired national education. Educational values, methods and layouts used by the relevant organizations must be ethnically developed and nationally armed. Ethnopedagogy, worked out from time immemorial, has been an obligatory tool for this kind of 
cultural perspectives of a progressive differentiated approach in teaching. In this case, it is significant to deepen into the essence, tools and methods of ethnic education, attention to the customs and tactics of the people. Ethnopedagogy fully affects many facets of social reality, building the way of thinking of the bearer of culture. Speaking about ethnic customs and thoughts, it is in no way possible to miss the significance of this science.

In general, ethnopedagogy, in its methodological role, is capable of being realized in today's project field. As you know, the more significant the numerical scatter between the action that needs to be formed and the actions that took place in a similar field before, the more significant will be the number of direct projects working on the methodology. And it is this methodological regularity that can be seen today in the persisting actual ethnopedagogical line of the North Caucasian (including Adyghe) national cultures. Revealing, generalizing, restoring ethnic traditions in developing adolescents' sense of national pride alongside the rules of interethnic respect is what ethnopedagogy can offer today as a nationwide anti-crisis method. However, there is a possible complication on this regional path: firstly, bilingualism, and secondly, society:

1. Bilingualism. The patterns, types and strategies of researching popular educational tendencies, ethnic methodological developments in teaching a youth to patriotism and intercultural tolerance in the field of the prevailing domestic bilingualism are the object of intense attention to them from practicing teachers, family members, and society. Complications due to bilingualism are very noticeable and cannot be easily and immediately ended, which is confirmed today by a number of studies carried out in relation to the regions.

2. Society. Scientists often correlate the levels of upbringing that exist in accordance with various social groups not only with attribution to different settlement types, but also with the lack of initial educational channels. A significant number of urban children, neither in family, nor in educational institutions, nor in society, can find the attitude they require to their personal difficulties of character formation.

Proceeding from the above-described necessity and the aforementioned difficulties, today there is an increasing appeal to the previously existing, ingrained models of the family didactic environment. A significant motive for this is provided by the intensified restoration of the ethnic originality of nations, which also carries folk original educational methods and methods. Nevertheless, the main thing is that under the circumstances existing in society, the development and strengthening of ethnopedagogical methods has a meaningful predestination on the part of the participant, divided into two emotional lines, caused on the one hand by the upcoming action, on the other by the results of the work already done. Although this is elementary, thorough and crude, maladaptive repetition of what is produced is not necessary and often even unhealthy. And therefore, the analysis of the required methods and their development in relation to the linguistic and social environment should be rich in content and aimed at potential study. By the way, let us mention here the aspects of the study of ethnopedagogical topics both in the domestic and in the regional scientific arena. The problems of improving the component of education (both secondary and higher) are considered in the works of V.F. Afanasyeva, G.N. Volkova, V.V. Kraevsky, I.K. Zhuravleva, I. Ya. Lerner, Z.P. Vasiltseva, M.N. Skatkin, B.C. Ledneva and others. In our work, we also took into account the regional Adyghe component in the field of study, including an appeal to the problem by G.M. Mambetova, M.A. Mamkhegova, S.Kh. Mafedzeva, M.A. Meretukova, B.Kh. Bgazhnokov, K.I. Buzarova, M.B. Gurtueva, M.G. Zagazezheva, A.E. Izmailova, S.S. Kirzhinova, E.L. Kodgesau, V.V. Makaeva, Sh.A. Mirzoeva, Yu.K. Namitokova, I.A. Shorova, Z. Ya. Yakubova, Ya. I. Khanbikova, E.E. Khataeva and others. Thus, since the advent of pedagogy in the human environment and up to our time, society and science have collected an impressive educational resource, formed their own views, methods and techniques in relation to this leading branch of the existential activity of the ethnos. Nevertheless, although there is such a very tangible interest in 
the scientific and social world, ethnic pedagogy today, due to its large-scale and centuriesold national resource, has a noticeable, far from exhausted potential for a researcher.

The prevailing currently accepted, civilizational scenario that exists today is mainly attributed by scientists to the postindustrial model. According to the sociologist P. Risman, who introduced the component "post-industrialism" into the conceptual structure, "the phenomenon of the information society cannot be substantiated outside the concept of postindustrial development" [5, p. 58]. At the same time, sometimes some scientists correlate the concept of an information-intensive society and sometimes draw an analogy with postindustrialism. The works also highlight the position of awarding the post-industrial and supposedly following it to the informational social environment of evolutionary quality. For example, in A.V. Kostina's dissertation work of 2006, there is a reference to the corresponding trilogy of the Spanish Marxist sociologist who dealt with the problems of the way of life of the modern city, M. Castells "The Information Age: Economy, Society and Culture" [3, p. 30-31]. Other scientists (in particular, the late Russian philosopher and sociologist V.S. Stepin) do not want to agree with the priority of the golden fleece and, arguing with it, propose a scenario for a new kind of spiritual and moral transformation of technocratic, not always restrained, freedoms, built on the dialogization of cultures [6, p. 32].

The target complex of our research can be considered the study of ethnic grounds for the formation of the scientific and pedagogical arsenal required for the productive inculcation of a feeling of love for his family and respect for a neighboring nation in a teenager, taking into account the circumstances of the bilingual domestic social environment. One of the components of this target complex is to consider the relevance and feasibility of using the Adyghe ethnopedagogy in modern (both theoretical and applied) didactics. Within any of the constituent components, there is an impressive series of specific target attitudes and their constituent methodological tasks. From the perspective of the problems we are studying, it is the methodological approach to ethnopedagogy that is quite active. Its content lies in the admissibility of detecting methodological techniques and in building a complex out of them on the basis of several interactions. Such a strategy gives its own peculiarity of summing up, the consideration of which it makes sense to continue in the future, viewing various components of ethnopedagogy as a method, suggesting to structure them along certain thematic lines corresponding to the qualities and characteristics of this method. Initially, his methodological techniques are presented as tools for building a previously unknown action, which makes it possible to establish the design necessary in this way. Further, these ethnopedagogical techniques work in the role of general information, concentrating information previously performed actions. Correlation of knowledge expected in methodological attitudes as in the methods of performing actions, and knowledge carried out from previous activity, makes it possible to understand the logic of a number of peculiar modifications occurring within the methodology. Thus, the study of theoretical and methodological basic resources of national (in particular, Adyghe) ethnopedagogy identified the historical and pedagogical conditioning, foundations and sociocultural circumstances of the development of this issue as an object of scientific thought, which appears as a rich didactic resource, a thorough study of which contributes to the achievement of tactical educational and educational purposes.

Ethnopedagogy traditionally contains two central cores: ethnic content with popular thought and national predestination of the existing methods. The first includes directly the culture of the nation and the world dominants passed through its filters. Another one is represented by techniques that allow one to optimally and productively take into account the direct psychological characteristics and mentality of the people's representatives. This twosided construction of ethnopedagogy actually predetermines its methodological value, an elementary and obligatory configuration. In our opinion, one of the possible projects for the constructive use of the resources of the ethnic pedagogy of the Circassians in the course 
of today's education is a specific educational project based on family habits and rules of education. It is capable of including a considerable number of rather closed practical moves, which are further subjects of theoretical study, and an open applied move that can be eaten away by means of methodological guidelines. The study of the theoretical and methodological foundations of adolescent Adyghe education can act as a tangible groundwork for the development of an appropriate project. The above-described components are structured into a single whole directly by methodological units through description and design. So, in particular, an educational book on ethnopedagogy was created for the first time not only in the Russian, but also in the world scientific arena by G.M. Volkov only in the late $90 \mathrm{~s}$ of the $20^{\text {th }}$ century (Moscow, 1999). For a long time required in the pedagogical niche, it was especially expected by employees of a junior educational institution. When studying ethnopedagogy from the standpoint of origin and the associated transformation of an active learner, it is permissible to say that in the process of forming methodological foundations that guarantee the development of new actions, the learner seems to leave the framework of the actions that were previously available in his arsenal. Thus, he finds himself in relation to his previous baggage in a reflective position. So, in this case, B. Ridler advises to consider your own individual value differently, and, thereby, transform your personal judgment about your capabilities and talents. This quality can be fully attributed to the peculiar functional features of the action based on the methodology. By drawing and outlining the reflexive leap of the actor beyond the boundaries of the previously performed options of action by the way we accept above, the methodology gains the potential thanks to which it is permissible to continue the guided study: 1) go into details when describing the constructed components and their relationships; 2) continue the construction further, outlining the stages and tools for systematizing and deepening methodological actions. So, in particular, G.N. Volkov, in the course of further reprints, plans to significantly supplement the methodological content of the textbook by means of specific chapters, such as an ethnopedagogical workshop, an ethnopedagogical seminary.

If we turn to the problem of state attention to ethnopedagogy today, we can note the following. Ethnic cultures and folk methods in the multinational Russian Federation for several decades since the collapse of the USSR have continued to be out of sight of the state and its cultural policy. As a result, there was a danger of losing ethnic originality. A number of young representatives of nations have emerged such, in addition to those already noted by us above, singled out by the Adygeyan teacher A.Kh. Dzamykhov today character traits such as "social apathy, ethnically leveled consciousness" [2, p. 4] and so on. Or in the works of another modern North Caucasian researcher I.A. Dadov discovered fresh lines in the study and in the applied application of the ethnopedagogical developments of the Circassians, which provided effective motivation for attempts to partially restore national didactics. As the scientist hillustrates, using extensive practical material in his dissertation work, the proposed methodology, based on ethnopedagogy, contributes to the development of students and their parents, as well as teachers, of measures of their own spiritual value and intercultural respect. I.A. Dadov considers a convincing visual embodiment of the described nationwide processions and festivities, extensively, effectively taking place in the territories of the KBR in accordance with the ethnopedagogical development he deduces. Since an all-embracing civilizational circle lurks within the limits of customs, although it is subject to systematization by means of scientific standards, it will invariably be able to keep a research secret in itself.

The introduction of ethnopedagogy techniques into the educational environment and practice is burdened by the lack of knowledge of their applicability. In the methodology, situations are possible if the strategies of actions developed by the methodologists have never been presented by anyone before and therefore, accordingly, there are no examples of it, which should have been proposed in the methodological instructions. Such underde- 
velopment is applicable to ethnopedagogy, however, methodological provisions, despite this, must be presented. Decreasing the value of national pedagogical tendencies can lead to a deterioration in the degree of preparedness of students. And therefore, an ethnopedagogical project proposal can be developed not only in the form of an image of previously performed actions, but also, preferably, in the form of a field for planned actions. Moreover, no matter how fresh and previously unknown the planned program may be, the project site itself is capable of becoming independent only if the existing experience of actions is taken into account. Often, if a grief happens in the Adyghe house (for example, someone's death), a teenager is able to take on an adult share of responsibilities. During the further period of growing up, they periodically try to compensate for this. As the psychologist of the new century B. Riedler explains this personality trait of children, "They tend to be hyperresponsible or care too much about others. Whether a tragedy happened or not is not that important in itself. What is important is how the child explains to himself what is happening. In other words, what does he think about life, about himself and about other people" [4, p. 52]. What the adolescent train of thought that carries it is capable of acting in this case, and how the project of new actions presented by the tactics of ethnopedagogy will be able to adapt to these statements, all this is the sphere of ethnopedagogy that should develop at the junction with child psychology.

In general, the development of personal priorities (both in the past and in our time) directly correlates with the ethnic attitudes of the representative of the culture, including the components of the national way of life and thought, which is directly manifested in the ethno-pedagogical attitudes inherent in the nation. Thus, the didactic approaches, folk methods and tactics of education and training, developed by the national way of life of the Circassians, are manifested, their comparative-analytical identification and generalization with the expectation of the modern educational sphere. Scientists dealing with ethnopedagogical problems manage to clarify specific customs in the educational process; explain in the mainstream of the Adyghe mentality the specifics of the influence on the individual of the house, language, art of ancestors; make a description of the available techniques in terms of ethnic culture. All this taken together makes it possible today to more consciously approach the laws of the Adyghe ethnopedagogy and present it as an effective method in the context of the globalization crisis. Refusal from such an ethnic resource can give rise to an underdeveloped person, since personal development by means of ethnic didactics is a coordinated mechanism that takes into operation the existing physiological and mental characteristics of an individual. As a result, firstly, in the course of the educational process it is necessary to be based on the ethnopedagogical experience of ancestors; secondly, at the same time it is required to pay attention to the development of the student's scientific interest, attention to contemporary civilization and its technologies. Such an attitude is undoubtedly significant, since it makes it possible to determine (both intuitively and accurately) the mutual influence of information on a diverse information field in the modern world.

\section{Лumepamypa}

1. Дзамыхов A.X. Роль фольклора в воспитании личности ребенка в семье: Авторефрерат дисс. ... к. пед. н. Махачкала, 2004. 24 с.

2. Костина А.В. Массовая культура как феномен постиндустриального общества. М.: КомКнига, 2006. 350 с.

3. Ридлер Б. Понимание себя и других. М.: Авваллон, 2006. 184 с.

4. Рисмен П. Грядущее информационное общество. Минск: Белорусская наука, 2006.

5. Степин В.С. Проблема будущего цивилизации // Будущее России в зеркале синергетики. М: СДР Центр, 2006. С. 35-45 
6. Sessah M.F. Primary school teachers' attitude towards the teaching of science // International Invention of Scientific Journal Vol 04, Issue 05, May 2020. pp. 11151136

\section{References}

1. Dzamikhov A.Kh. Rol folklora v vospitanii lichnosti rebenka v semye: Avtoreferat diss. [The role of folklore in the upbringing of a child's personality in a family: Abstract of a dissertation]. Makhachkala, 2004. 24 p. (In Russian).

2. Kostina A.V. Massovaya kultura kak fenomen postindustrialnogo obshchestva [Mass culture as a phenomenon of post-industrial society]. Moscow: KomKniga, 2006. 350 p. (In Russian).

3. Ridler $B$. Ponimaniye sebya i drugikh [Understanding yourself and others]. Moscow: Avvallon, 2006. 184 p. (In Russian).

4. Risman P. Gryadushcheye informatsionnoye obshchestvo [The coming information society]. Minsk: Belarusian Science, 2006 (In Russian).

5. Stepin V.S. Problema budushchego tsivilizatsii. [The problem of the future of civilization] Budushcheye Rossii v zerkale sinergetiki. Moscow: SDR Center, 2006. pp. 35-45 (In Russian).

6. Sessah M.F. Primary school teachers' attitude towards the teaching of science. International Invention of Scientific Journal. V.4. Issue 5. May 2020. pp. 1115-1136 (In Russian). 